\title{
A Comparative Analysis of the Engagement Resources of Chinese and American Newspapers on Hong Kong National Security Law
}

\author{
${ }^{1}$ School of Foreign Languages, Shaoguan College \\ *Corresponding author. Email: Tainiflick20@163.com
}

Zhuo Peng ${ }^{1, *}$

\begin{abstract}
This paper compares the differences of engagement resources in the news on Hong Kong National Security Law between People's Daily and The Washington Times with the help of the Engagement System of Appraisal Theory, and analyzes the causes of the differences. The results show that: both newspapers tend to use monogloss sentences and trigger heterogloss dialogues from respective positions of supporting their own countries, People's Daily has higher proportion of dialogic contraction resources, while The Washington Times has higher proportion of heterogloss resources and dialogic expansion resources; The differences of ideology between China and the US are the reasons for the above differences. This study can promote China's localization research of the Engagement System of Appraisal Theory, and contribute to constructing a discourse system for safeguarding China's sovereignty.
\end{abstract}

Keywords: Hong Kong National Security Law, Chinese and American newspapers, engagement resources, contrast, ideology

\section{INTRODUCTION}

From June 2019 to June 2020, there was social unrest in Hong Kong caused by the legislative amendment. In order to maintain the prosperity and stability of Hong Kong and the steadiness of the rule "one country two systems", the 20th session of the Standing Committee of the 13th National People's Congress of China voted and passed the Law of the People's Republic of China on Safeguarding National Security in the Hong Kong Special Administrative Region (hereinafter referred to as Hong Kong National Security Law). During the deliberation of the law, American politicians and newspapers have been maliciously attacking the law. And Chinese Ministry of Foreign Affairs and newspapers have made timely response and counterattack. At present, few scholars study the news on Hong Kong National Security Law, and few scholars compare the news on the law in Chinese and American newspapers. In addition, there are usually many voices in the news, and engagement resources are the key to construct these voices [1]. In view of this, this paper, with the help of the Engagement System of Appraisal Theory, makes a comparative analysis of the differences of engagement resources in the news on Hong Kong National Security Law between
Chinese and American newspapers, and explores the causes of the differences. This study can provide enlightenment for Chinese media to fight back against the attacks of American media, and promote China's localization research of the Engagement System of Appraisal Theory.

\section{ENGAGEMENT SYSTEM}

Appraisal Theory, proposed by Martin \& White [2], is to develop the interpersonal functions of Systemic Functional Linguistics. It deals with the types of attitude, emotional intensity, and various ways of expressing value and aligning readers in discourse negotiation [3]. This theory includes three subsystems: Attitude, Engagement and Graduation. Engagement refers to the language resources used to indicate the sources of the voice of the discourse or the author. For example, discourse can be the author's voice or the external voice introduced by the author [3]. The Engagement System consists of two subsystems: Monogloss and Heterogloss, and the latter further includes two subcategories: dialogic contraction and dialogic expansion [3], as is shown in Figure 1. 


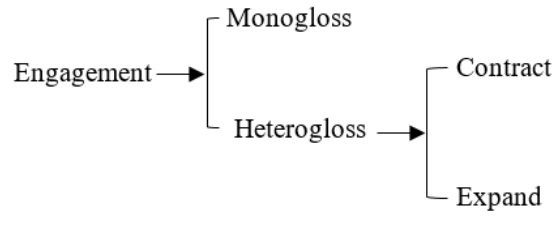

Figure 1 Engagement System.

Monogloss means that when a speaker or an author presents a proposition, he or she does not refer to other voices or opinions that can replace the proposition, while heterogloss refers to that a speaker or an author quotes or considers other voices or opinions that can replace his or her proposition [2]. Dialogic contraction means that a speaker or an author challenges, counterattacks or limits other voices or opinions when expressing propositions, thus he or she compresses the dialogic space; dialogic expansion means that a speaker or an author's propositions more or less trigger other voices or opinions, thus expanding the dialogic space [3]. Dialogic contraction includes the subcategories of deny, counter, concur, pronounce and endorsement, while dialogic expansion includes the subcategories of entertain, acknowledge and distancing. This study focuses on the engagement resources above the subcategories of dialogic contraction and expansion.

\section{RESEARCH DESIGN}

\subsection{Research Questions}

We select the news on the mass basis, justification and applicability of Hong Kong National Security Law from People's Daily and The Washington Times as the research data, and compare the differences of engagement resources in the above news of the two newspapers. Specifically, we explore two questions: 1) What are the differences in the distribution of engagement resources of the above news in the two newspapers? 2) What are the reasons for the differences?

\subsection{Research Procedure}

First of all, we search for the news on the mass basis, justification and applicability of Hong Kong National Security Law from May to July 2020 in the electronic editions of People's Daily and The Washington Times, and select 20 pieces of news from each newspaper. Secondly, the selected news of the two newspapers are copied separately into two Microsoft Word documents to construct Chinese and English parallel corpora. The Chinese corpus contains 20866 tokens and the English corpus contains 13715 tokens. Thirdly, according to the Engagement System in Figure 1, we manually identify the types of engagement resources in two corpora, and invites another teacher from our college to inspect the results. Finally, we count the amount and the proportion of each kind of engagement resources in each piece of news, and compare the differences in the proportion of engagement resources in the two corpora with the help of Independent Samples T-test of SPSS 25.0.

\section{DIFFERENCES IN ENGAGEMENT RESOURCES}

From the above definition of monogloss and heterogloss, we can see that the distinction between them is based on propositions, and propositions are often carried by sentences. Therefore, we count the amount of monogloss sentences. There are 60 and 375 monogloss and heterogloss sentences in Chinese corpus, and 80 and 485 monogloss and heterogloss sentences in English corpus. Among them, 60 monogloss sentences in Chinese corpus embody the position of supporting China (hereinafter referred to as pro-China position); 8 monogloss sentences in English corpus show pro-China position, and 72 sentences reflect the position of supporting America (hereinafter referred to as proAmerica position).

We count the amount of different types of monogloss sentences in each piece of news and calculate their proportion to the total amount of sentences in each piece of news (hereinafter referred to as sentence proportion), and uses the Independent Samples T-test of SPSS 25.0 to compare monogloss sentence proportion, pro-China monogloss sentence proportion and pro-America monogloss sentence proportion in the above two corpora. The results are: $\mathrm{T}=-0.050, \mathrm{P}=0.960>0.05 ; \mathrm{T}=6.988$, $\mathrm{P}=0.000<0.001 ; \mathrm{T}=-8.099, \mathrm{P}=0.000<0.001$. As can be seen from $\mathrm{P}$ value, there is no significant difference in the monogloss sentence proportion between People's Daily and The Washington Times, but there are significant differences at the level of 0.001 in the latter two categories. According to T value, we know that People's Daily uses more pro-China monogloss sentences, while The Washington Times adopts more pro-America monogloss sentences. All in all, both newspapers prominently use monogloss sentences with the position of supporting their own countries.

Heterogloss system is basically a lexical semantic system. In other words, a sentence may contain multiple heterogloss resources, for example, in the sentence "I hope there's no violence in these public demonstrations because you cannot win", there are dialogic contraction resources (no, not) and dialogic expansion resources (I hope, can). Thus, we consider vocabulary and grammar as the clues to identify and count the amount of heterogloss resources. The Chinese corpus contains 1049 heterogloss resources, of which 1049 resources embody pro-China position and no resources show pro-America position; the English corpus includes 1102 heterogloss resources, of which 184 resources reflect pro-China position and 918 resources embody pro-America position. 
Basing on the above statistics, we calculate the proportion of heterogloss resources to the total amount of tokens in each piece of news, that is, the density of heterogloss resources in each piece of news. We adopt Independent Samples T-test to compare the two groups of proportion in Chinese and English corpora, and the result is: $\mathrm{T}=-6.367, \mathrm{P}=0.000<0.001$. From $\mathrm{P}$ value, we can see that there is a significant difference at the level of 0.001 in heterogloss resources between the two newspapers. And from $\mathrm{T}$ value, we can see that the density of heterogloss resources in People's Daily is lower than that in The Washington Times. Heterogloss resources can introduce other voices in varying degrees, and reserve certain dialogic space for other voices. All in all, The Washington Times has relatively strong dialogism.

We calculate the proportion of pro-China and proAmerica heterogloss resources to the total amount of heterogloss resources in each piece of news (the proportion of various kinds of heterogloss resources to the total amount of heterogloss resources in each piece of news is hereinafter referred to as the resource proportion), and compare the differences between the above two types of heterogloss resource proportion in Chinese and English corpora by means of Independent Samples T-test. The results are: $\mathrm{T}=18.175, \mathrm{P}=0.000<0.001 ; \mathrm{T}=-18.175$, $\mathrm{P}=0.000<0.001$. According to the $\mathrm{P}$ value, there is a significant difference at the level of 0.001 between the People's Daily and The Washington Times both in the pro-China and pro-America heterogloss resources proportion. It can be seen from the T value that People's Daily uses more heterogloss resources with the proChina position, while The Washington Times adopts more heterogloss resources with the pro-America position.

As can be seen from the above, heterogloss resources can be divided into two subcategories: dialogic contraction and dialogic expansion, and these two types of resources can be further divided into pro-China and pro-American subcategories. With the help of Independent Samples T-test, we compare the differences between Chinese and English corpora in six aspects: the proportion of dialogic contraction resources and dialogic expansion resources, the proportion of pro-China dialogic contraction resources and pro-America dialogic contraction resources, the proportion of pro-China dialogic expansion resources and pro-America dialogic expansion resources. The results are: $\mathrm{T}=5.705$, $\mathrm{P}=0.000<0.001 ; \mathrm{T}=-5.705, \mathrm{P}=0.000<0.001 ; \mathrm{T}=11.686$, $\mathrm{P}=0.000<0.001 ; \mathrm{T}=-9.470, \mathrm{P}=0.000<0.001 ; \mathrm{T}=10.937$, $\mathrm{P}=0.000<0.001 ; \mathrm{T}=-16.323, \mathrm{P}=0.000<0.001$. According to the $\mathrm{P}$ value, there are significant differences between People's Daily and The Washington Times at the level of 0.001 in the above six aspects. It can be seen from the $\mathrm{T}$ value that People's Daily's proportion of dialogic contraction resources, pro-China dialogic contraction resources and pro-China dialogic expansion resources is relatively higher than The Washington Times' corresponding proportion; while The Washington Times' proportion of dialogic expansion resources, Pro-America dialogic contraction resources and Pro-America dialogic expansion resources is relatively higher than People's Daily's corresponding proportion. The results indicate that People's Daily uses the resources of dialogic contraction, and pro-China dialogic contraction and expansion resources relatively more, while The Washington Times does the opposite.

To sum up, the two newspapers tend to use monogloss sentences with the position of supporting their respective countries; the density of heterogloss resources of People's Daily is lower than that of The Washington Times; the two newspapers tend to take the position of supporting their respective countries to trigger heterogloss dialogue and exploit dialogic contraction and expansion resources; People's Daily uses more dialogic contraction resources while The Washington Times exploits more dialogic expansion resources.

\section{CAUSES OF THE DIFFERENCES}

Media often reflect the politics, culture and ideology of their own countries. Therefore, it is normal for the two newspapers to use the engagement resources with position of supporting their respective countries. It can be seen from the above that the heterogloss resource density of People's Daily is lower than that of The Washington Times, and the former uses more dialogic contraction resources, while the latter uses more dialogic expansion resources. Therefore, the dialogism of the news in People's Daily is weaker than that in The Washington Times, that is, The Washington Times constructs dialogic space for other voices to greater extent, so as to form an alliance with potential readers with different views and hope that readers can accept the views in the newspaper or at least acknowledge the views in the newspaper while admitting the existence of different views.

After the "9.11" attack, two anti-terrorism wars and the international financial crisis in 2008, the economic strength of America has obviously declined [4]. At the same time, the development of multilateralism and globalization since the $21 \mathrm{st}$ century has affected American hegemony, while China's economy has grown rapidly [5]. The US needs to exploit the social unrest in Hong Kong to restrain China's development, and build an anti-China united front by resisting Hong Kong National Security Law (for example, forming an alliance with Britain and Australia to belittle Hong Kong National Security Law), so as to strengthen its control over all allies and consolidate its global hegemony [6]. The Washington Times reflects the ideology of US government, so it will comply with the needs of the government. In short, the hegemonic ideology of the US causes the US media to unit external voices to resist Hong Kong National Security Law. 
People's Daily uses relatively more dialogic contraction resources, which can resist the intervention of other voices and compress the dialogic space, so as to make the authors' proposition difficult to refute, thus, it can increase the interpersonal cost of challenging its proposition and effectively suppress or counterattack different or opposite views [7]. It can be seen that People's Daily has a firm and tough attitude in safeguarding Hong Kong National Security Law and fighting back against the US media. The reason is that the US media's unreasonable derogation of the law interferes in China's internal affairs and damages China's reputation. People's daily, as the faithful spokesman of Chinese government, will make a strong response and counterattack. China is the biggest beneficiary of the development of economic globalization in the past 30 years, and its economic strength and comprehensive national power have been significantly enhanced [5], which makes Chinese media become more confident on the international stage and their attitude of protecting the country be stronger. All in all, the use of engagement resources in the media is closely related to China's ideology of adhering to national independence and resolutely safeguarding national interests.

\section{CONCLUSION}

With the help of the Engagement System of Appraisal Theory, this study compares the differences of engagement resources in the news on Hong Kong National Security Law between People's Daily and The Washington Times, and analyzes the causes of the differences. Both research questions of this study have been answered. First of all, the two newspapers tend to exploit monogloss sentences and initiate heterogloss dialogues based on supporting their respective national positions. People's Daily has a relatively higher proportion of dialogic contraction resources, while The Washington Times has a relatively higher density of heterogloss resources and higher proportion of dialogic expansion resources. Secondly, the ideological differences between China and the US are the causes for the above differences.

This study reveals that People's Daily uses relatively more dialogic contraction resources. In view of the US hegemony and the ideology of constructing anti-China united front, we think that Chinese media can exploit more dialogic resources when they fight back against US media, so as to ally various readers to resist the derogation of Hong Kong National Security Law by US media, and let the international community feel that Chinese media can not only convince people by reasons, but also move people by affection, and constantly improve the intimacy and acceptability of Chinese media discourse [8], and ultimately build a discourse system for safeguarding China's sovereignty. This study not only provides enlightenment for Chinese media to fight back against the attack of the US media, but also contributes to the construction of a discourse system to safeguard China's sovereignty. It can also help promote the localization research of Engagement System of Appraisal Theory in China.

\section{ACKNOWLEDGMENTS}

Research for this study is sponsored by Guangdong Province Educational Science Project (No. 2020GXJK071); Shaoguan College Research Project (No. SZ2020SK02).

\section{REFERENCES}

[1] S. Z. Liu, J. L. Han, Appraisal System in News Discourse, Technology Enhanced Foreign Language Education (4) (2004) 17-21.

[2] J. R. Martin, P. R. R. White, The Language of Evaluation: Appraisal in English, Palgrave Macmillan, New York, 2005.

[3] Z. L. Hu, Y. S. Zhu, D. L. Zhang, Z. Z. Li, An Introduction to Systemic Functional Linguistics (The Third Edition), Peking University Press, Peking, 2017.

[4] J. F. Liu, The Impact of the Novel Coronavirus Pneumonia on International Configuration, Contemporary World and Socialism (3) (2020) 12 19. DOI: https://doi.org/10.16502/j.cnki.113404/d.2020.03.002

[5] Q. Zhou, A Review of China-U.S. Relations under Globalization after COVID-19 Pandemic, Contemporary World (6) (2020) 4-12. DOI: https://doi.org/10.19422/j.cnki.ddsj.2020.06.001

[6] K. J. Zhao, "Soft War" and Its Roots: China-U.S. Interactions during the Covid-19 Pandemic, The Chinese Journal of American Studies (3) (2020) 934.

[7] Y. Lai, B. Xin, Analysis of Intertextual Rhetoric Function in English News Texts - From a Perspective of Appraisal Theory, Contemporary Rhetoric (3) (2012) 25-32. DOI: https://doi.org/10.16027/j.cnki.cn312043/h.2012.03.014

[8] F. Fang, Analyzing the News Discourse in the South China Sea Arbitration Case from the Perspective of Appraisal Theory, Journal of Hainan University (4) (2015) $17-22$. DOI: https://doi.org/10.15886/j.cnki.hnus.2015.04.003 